\title{
THE MAINTENANCE DIET IN DIABETES MELLITUS AS DETERMINED BY THE NITROGEN EQUILIBRIUM *
}

\author{
HERMAN O. MOSENTHAL, M.D. \\ AND \\ SAMUEL W. CLALSEN, M.D.
}

In the treatment of diabetes mellitus there are two guiding principles which determine the caloric value of the diet. In the first place, the quantity of carbohydrates, proteins and fats offered the patient must be within his carbohydrate tolerance; that is, the diet must be so regulated that the urine remains sugar-free. It is generally acknowledged that under these circumstances the disease itself is treated in the most effective manner. Secondly, a diet of sufficient caloric value should be offered the patient so that his health and strength may be maintained at a normal level. It is readily appreciated that these two guiding principles of treatment are diametrically opposed to each other in many respects. The one demands a restricted diet, and in many instances, undernutrition; the other calls for a larger amount of food. The first aims at treating the disease, diabetes mellitus; the second artempts to conserve the nutrition of the patient. The neglect of either factor may entail undesirable results.

During the past years emphasis has been continually placed on the dietary restriction and the prevention of glycosuria. Previously, on account of lack of full appreciation of the results which could be obtained by a more drastic curtailment of the food calories, this idea was not pushed to its logical conclusion of controlling the glycosuria of nearly every diabetic patient. Through the efforts of F. M. Allen, by systematic and radical reductions in the food, this may be easily accomplished in most cases. ${ }^{1}$ The widespread use of these very limited diets has brought up the question of how little the individual may eat and yet remain physically and mentally fit. It is the object of the present paper to furnish at least a partial answer to this question.

At present it is believed that "diabetics generally have no higher food requirement than normal, and, on account of undernutrition and lessened muscular activity, will tend to maintain equilibrium on a smaller number of utilizable calories than normal persons." ${ }_{2}$ One factor which the above statement implies is that the lower the nutri-

* Submitted for publication Nov. 26, 1917.

* From the Medical Clinic of the Johns Hopkins Hospital.

1. Allen, F. M.: Boston Med. and Surg. Jour., 1915, 172, 241.

2. Allen, F. M., and Du Bois, E. F.: The Archives Int. Med., 1916, 17, 1010. 
tional state of a diabetic or anyone else becomes, the less will be the food requirements necessary to reach a maintenance level. When such a subnormal state is reached, and the main object of treatment is to keep the patient alive and not necessarily efficient, a partial failure in our therapeutic aims must be acknowledged. The maintenance diet, under ideal conditions, should be sufficiently high not only to enable the patient to live, but also to carry on an average amount of physical and mental work without undue fatigue.

The standard for maintenance for the diabetic may be sought for in one of two criteria: first, the caloric requirement, and second, the nitrogen equilibrium. The caloric requirement may be readily ascertained according to the height-weight formula of Du Bois and Du Bois. ${ }^{3}$ Food administered in accordance with this standard ${ }^{4}$ should satisfy all theoretic demands. The nitrogen equilibrium represents the lowest possible diet which could be exacted of any patient. Food, under these circumstances, results in the conservation of the protein tissues, but does not necessarily prevent the loss of fat. This principle has been applied in the treatment of obesity; it was successfully used in the prolonged dietetic experiments of Chittenden on normal people, and is employed here. No living being can afford to lose muscle and glandular tissue indefinitely. How far the fat store of any individual may be depleted with advantage is another question. There is much to be said in favor of allowing the diabetic to become thin, so that his metabolism may be established at a lower level, as has so frequently been urged, but it should be distinctly appreciated that this loss of weight should occur in the fats and not in the vitally necessary proteins. It is with these ideas in mind that the nitrogen equilibrium has been chosen as the lowest possible food standard by which diabetics may be maintained in a state of physical and mental wellbeing over long periods.

The kind of food provided for the diabetic may ultimately prove to be of more importance than is accredited to it at present. That a protein-fat diet low in carbohydrate should be employed is common knowledge. The proportion of fat and protein, however, and the height to which the protein-fat foods are raised before carbohydrates are added are still open questions which are answered in widely divergent ways by different clinicians. In the present observations the diets outlined in Tables 1 and 2 were used whenever possible. These are as low in fats as it is possible to make them and yet render them palatable over long periods, and they afford the maximum variety of which a carbohydrate-free list is capable. The low fat content of these diets was insisted on as being the most satisfactory manner in which to

3. Du Bois, D., and Du Bois, E. F.: The Archives Int. Med., 1916, 17, 863.

4. Gephart, F. C., and Du Bois, E. F.: The Archives Int. Med., 1916, 17, 902. 
TABLE 1.-Diets of Specified Caloric Value in Which the Fat Is Kept at a Low Level. The Protein and Fat Are Approximately Equal to Each Other, Gram for Gram. From These Tabulations, Approximate Diets of ANy Calnric Value May Be Readily Calculated. These ARE THE Diets Used IN MOST OF the Present Orservations ${ }^{j}$

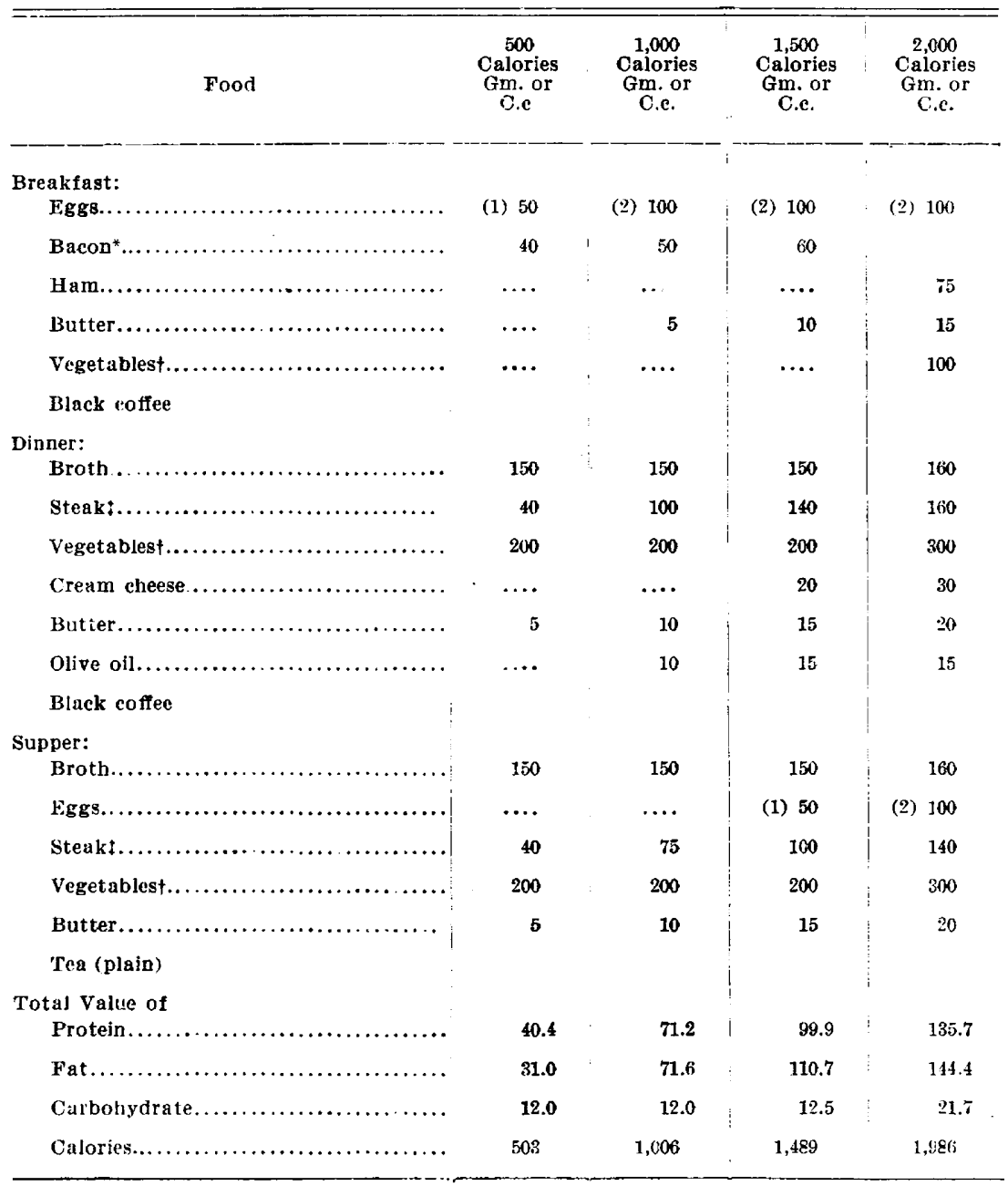

* The bacon is welghed uncooked. The fat and protein content is calculated for the cooked product.

$t$ Two or three difierent vegetables should le chosen from the accompanying list (Table 2), which tabulates the vegetables containing 5 per cent. or less of carbohydrates.

: The caloric equivalent of other carbohydrate-free meat or fish should be frequently substituted from the accompanying list (Table 2 ), to furnish variety in the diet.

5. For complete details of these diets, see Jour. Med. Soc. New Jersey, 1916 , 13, 339 . 
TABLE 2.-List of Meats, Fish and Vegetables Allowed in the Diets of Table 1. The Meats Are Tabulated in Units Approximately the Caloric Equivalent of 10 Gm. of Beefsteak, and May Be Substituted for the Same Caloric Value of Beefsteak in Table 1

CALORIC EQUIVALENT OF $10 \mathrm{GM}$. OF STEAK IN CARBOHYDRATE-FREE MEAT OR FISH

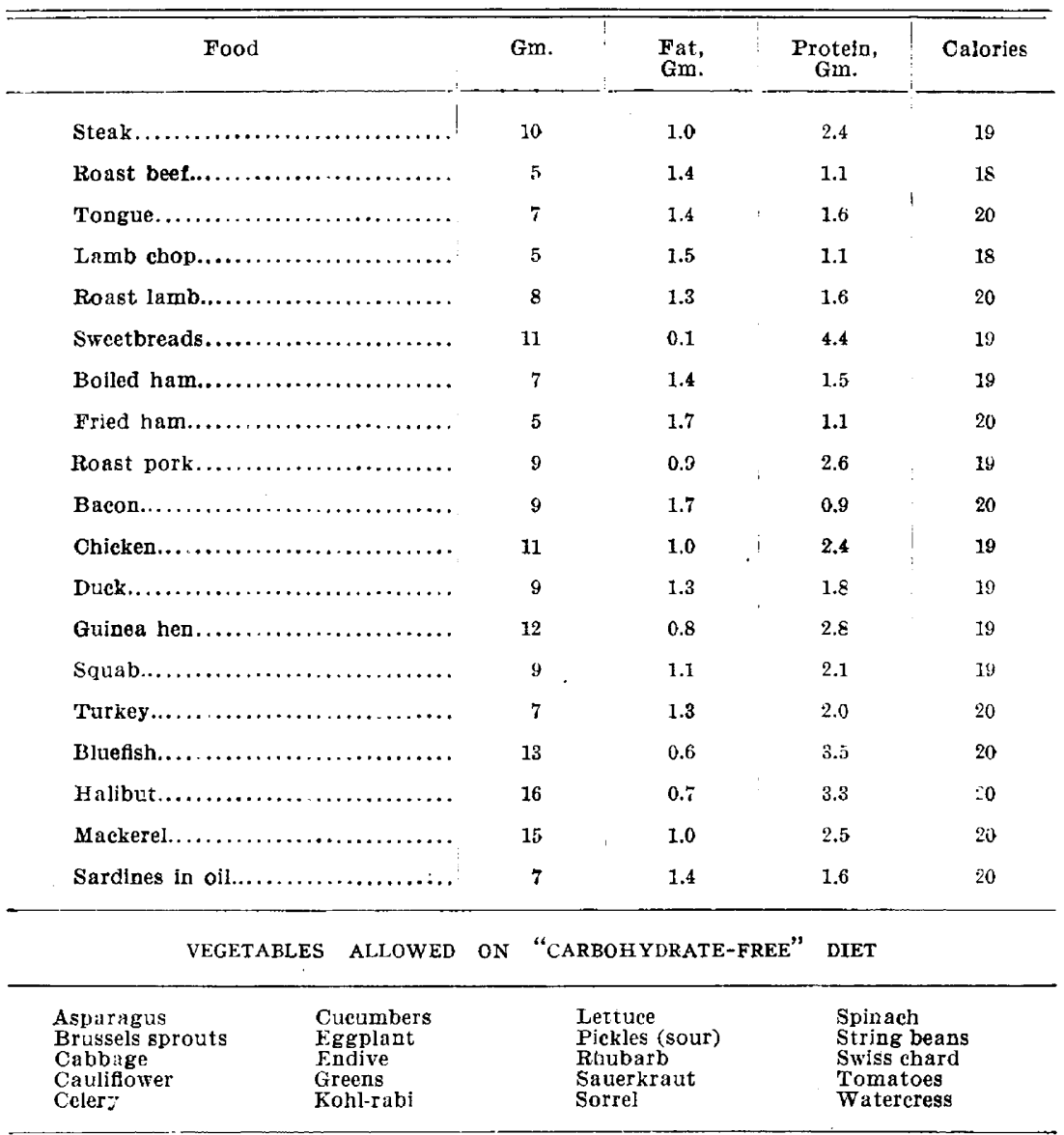

control acidosis. It may be noted that the fats and proteins remain approximately equal to each other, gram for gram, throughout these diets.

The nitrogen of the food was either calculated according to Atwater and Bryant's tables, ${ }^{6}$ or actually determined by analysis. The correspondence between the two methods was close enough to justify the use for the present purposes of the values as given in the tables. The nitrogen of the food, urine and feces were all determined by the

6. Atwater, W. O., and Bryant, A. P.: Bu1l. No. 28, U. S. Dept. Agric., 1906. 
Kieldahl method. Most of these patients were under strict supervision, either in a small metabolism ward or in the private rooms. Twentyfour cases were studied. Of these, only a few will be given in detail. The urinary glucose was estimated by Benedict's ${ }^{7}$ modification of Fehling's solution, the acetone substances in the urine by Shaffer's ${ }^{8}$ procedure, and the blood sugar by the method of Lewis and Benedict ${ }^{9}$ or that of Bang. ${ }^{10}$

The number of calories of the protein-fat diet necessary to bring about nitrogen equilibrium was found to be slightly greater than, equal to, or considerably less than the total average caloric requirement of persons of the same age and sex as the diabetics. (Tables 3 and 4.)

Since it is known that "if a given subject's basal metabolism is more than 10 per cent. from the average, it may be regarded as abnormal, but cannot be proved abnormal unless the departure is at least 15 per cent., ${ }^{11}$ it may be concluded that the amount of food demanded to result in a nitrogen balance is not greater, in any one of the present series of cases, than the upper limits of normal metabolism, but may be lower (Table 4). This finding for diabetics is in strict accord with that of E. Voit and Korkunoff, ${ }^{12}$ who demonstrated that under normal conditions, "if fat and meat be ingested together, the quantity of the latter necessary to establish nitrogenous equilibrium is reduced to between 1.6 to 2.1 , the starvation minimum."

The case ${ }^{13}$ detailed in Table 5 demonstrates at what a low level of metabolism a nitrogen balance may be obtained. This child was evidently an instance of "total diabetes." The D: $N$ ratio was constantly in the neighborhood of $3.65: 1$, indicating that no carbohydrate, derived either from the small amount of ingested starch or from the protein, was utilized. Inasmuch as starch, whether preformed or derived from protein, has been considered the most efficient sparer of nitrogen, it is remarkable that in this patient nitrogen equilibrium could be effected on a diet of 19 calories per square meter per hour, which is only a fraction of the normal standard. (Boys 12 to 13 years of age on such a diet may be considered to have normal standard of metabolism of 54.9 calories per square meter per hour; Gephart and Du Bois do not give any figures for the normal basal metabolism of girls.) On calculating the metabolism for the whole period of observation it is noted that although only $0.49 \mathrm{gm}$. of nitrogen were lost per day, yet the food

7. Benedict, S. R.: Jour. Am. Med. Assn., 1911, 57, 1193.

8. Shaffer, P. A.: Jour. Biol. Chem., 1908, 5, 211.

9. Lewis, R. C., and Benedict, S. R.: Jour. Biol. Chem., 1915, 20, 61.

10. Bang, I.: Biochem. Ztschr., 1913, 57, 300.

11. Gephart, F. C., and Du Bois, E. F.: The Archives Int. Med., 1916, 17, 906.

12. Lusk, G.: Science of Nutrition, Ed. 3, 1917, p. 254.

13. This patient was studied in the pediatric clinic under Dr. J. Howland; the blood sugar was determined by Harold L. Higgins. 
Table 3.-Condensed Data from Cases of Diabetes Mellitus, Which

Show, by Periods, the Relation of the Caloric Value of the

Diet to Maintenance, as Measured by the Nitrogen

EQuilibrium. The Daily Caloric Value of the

Food Was Approximately Constant

During Each Period

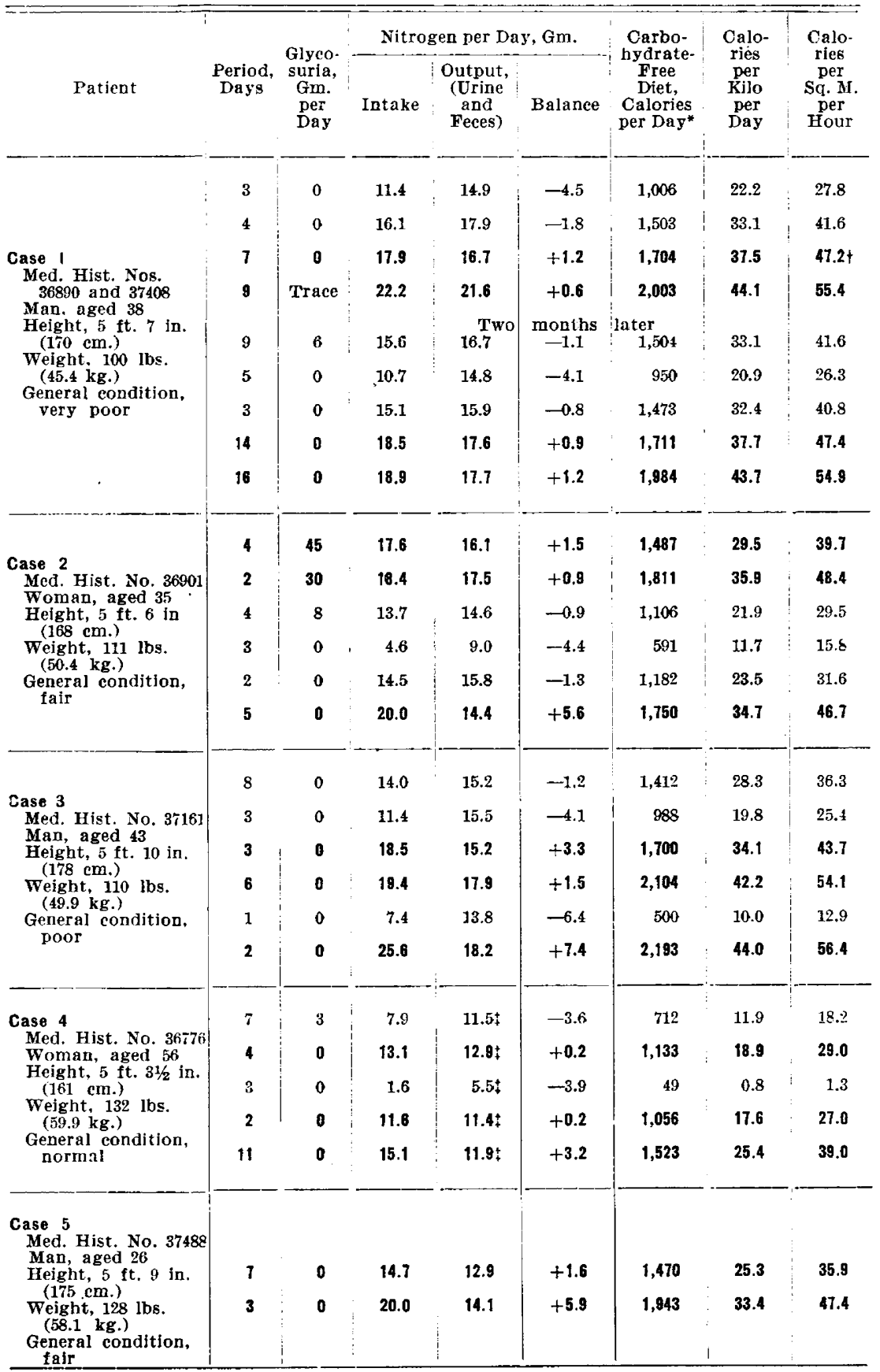

" "Carbohydrate-iree" diets contain approximately the proportion of proteing fats and carbohydrates given in Table 1 , with the exception of Cases 8 and 9 , in which the carbohydrate content of the food was somewhat higher. 
Table 3.-Condensed Data from Cases of Diabetes Mellitus, Which

Show, by Perions, the Relation of the Caloric Value of the Diet to Maintenance, as Measured by the Nitrogen

Equilibrium. The Daily Caloric Value of the

Food Was Approximately Constant

During Each Period.-

Continued

\begin{tabular}{|c|c|c|c|c|c|c|c|c|}
\hline \multirow[b]{2}{*}{ Patient } & \multirow[b]{2}{*}{$\begin{array}{l}\text { Period, } \\
\text { Days }\end{array}$} & \multirow[b]{2}{*}{$\begin{array}{l}\text { Glyco- } \\
\text { suria, } \\
\text { Gm. } \\
\text { per } \\
\text { Day }\end{array}$} & \multicolumn{3}{|c|}{ Nitrogen per Day, Gm. } & \multirow{2}{*}{$\begin{array}{l}\text { Carbo- } \\
\text { hydrate- } \\
\text { Free } \\
\text { Diet, } \\
\text { Calories } \\
\text { per Day* }\end{array}$} & \multirow{2}{*}{$\begin{array}{c}\text { Calo- } \\
\text { ries } \\
\text { per } \\
\text { Kilo } \\
\text { per } \\
\text { Day }\end{array}$} & \multirow{2}{*}{$\begin{array}{c}\text { Calo- } \\
\text { rjes } \\
\text { per } \\
\text { sq. M. } \\
\text { per } \\
\text { Hour }\end{array}$} \\
\hline & & & Intake & $\begin{array}{l}\text { Output, } \\
\text { (Urine } \\
\text { and } \\
\text { Feces) }\end{array}$ & Balance & & & \\
\hline \multirow{6}{*}{$\begin{array}{l}\text { Case } 6 \\
\text { Med. Hist. No. } 37267 \\
\text { Man, aged } 35 \\
\text { Height, } 5 \text { ft. } 7 \mathrm{in} . \\
\text { (170 cm.) } \\
\text { Weight, 100 lbs. } \\
\text { (54.4 kg.) } \\
\text { General condition, } \\
\text { normal }\end{array}$} & 4 & 45 & 12.6 & 15.5 & -2.9 & 1,318 & 24.2 & 33.8 \\
\hline & 3 & 22 & 10.2 & 14.7 & -4.5 & 988 & 18.2 & 25.3 \\
\hline & 5 & 0 & 5.4 & 10.9 & -5.5 & 421 & 7.8 & 10.8 \\
\hline & 4 & 0 & 13.3 & 12.0 & +1.3 & 1,099 & 20.2 & 28.2 \\
\hline & 4 & 0 & 15.9 & 13.6 & +2.3 & 1,465 & 26.9 & 37.5 \\
\hline & 8 & 0 & 18.0 & 15.5 & +2.5 & 1,728 & 31.9 & 44.3 \\
\hline \multirow{5}{*}{$\begin{array}{l}\text { Case } 7 \\
\text { Med. Hist. No. } 37261 \\
\text { Man, aged } 41 \\
\text { Height, } 5 \mathrm{ft} .8 \mathrm{in} . \\
\text { (173 cm.) } \\
\text { Weight, } 136 \text { lbs. } \\
\text { (61.7 kg.) } \\
\text { General condition, } \\
\text { normal }\end{array}$} & 6 & 5 & 15.6 & 23.6 & -8.0 & 1,503 & 24.4 & 36.1 \\
\hline & 5 & 0 & 15.6 & 17.3 & -1.7 & 1,505 & 24.4 & 36.1 \\
\hline & 3 & 0 & 17.0 & 17.1 & -0.1 & 1,614 & 26.2 & 38.7 \\
\hline & 3 & 0 & 18.8 & 23.1 & -4.3 & 1,903 & 30.8 & 45.6 \\
\hline & 3 & 0 & 21.4 & 19.8 & +1.5 & 2,048 & 33.2 & 49.1 \\
\hline \multirow{11}{*}{$\begin{array}{l}\text { Case } 8 \\
\text { Med. Hist. Nos. } \\
36887 \text { and } 37230 \\
\text { Boy, aged } 13 \\
\text { Height, } 4 \text { ft. } 11 \mathrm{in} . \\
\text { (150 cm.) } \\
\text { Weight, } 75 \text { lbs. } \\
\text { (34.0 kg.) } \\
\text { General condition, } \\
\text { normal }\end{array}$} & 12 & 0 & 8.2 & 9.9 & -1.7 & 609 & 17.9 & 20.9 \\
\hline & 3 & 0 & 13.4 & 10.8 & +2.6 & 1,152 & 33.9 & 39.5 \\
\hline & 2 & Trace & 12.6 & $16.9 \ddagger$ & -4.3 & 1,284 & 37.8 & 44.0 \\
\hline & 5 & 0 & 7.4 & $10.9 \ddagger$ & -3.5 & 595 & 17.5 & 20.4 \\
\hline & 9 & 0 & 13.5 & 14.6 & -1.1 & 1,157 & 34.0 & 39.6 \\
\hline & $\epsilon$ & 0 & 14.8 & 15.3 & -0.4 & 1,449 & 42.6 & 49.7 \\
\hline & 5 & 0 & 15.4 & 15.7 & -0.3 & 1,363 & 40.1 & 46.7 \\
\hline & 3 & 0 & 12.9 & ${ }_{15.2^{\mathrm{Six}}}$ & $\begin{array}{c}\text { weeks } \\
-2.3\end{array}$ & $\begin{array}{l}\text { later } \\
1,101\end{array}$ & 32.4 & 37.7 \\
\hline & 6 & 0 & 18.4 & 16.4 & +2.0 & 1,508 & 44.4 & 51.7 \\
\hline & 1 & 0 & 8.4 & 9.4 & -1.0 & 620 & 18.2 & 21.2 \\
\hline & 7 & 0 & 21.7 & 19.0 & +2.7 & 1,686 & 49.6 & 57.8 \\
\hline \multirow{8}{*}{$\begin{array}{l}\text { Case } 9 \\
\text { Med. Hist. No. } 36838 \\
\text { Girl, aged } 12 . \\
\text { Height, } 5 \text { ft. } 11 / 2 \text { in. } \\
\text { (156 cm.) } \\
\text { Weight, } 60 \text { lbs. } \\
\text { (27.2 kg.) } \\
\text { General condition, } \\
\text { poor }\end{array}$} & 1 & 0 & 5.9 & 13.4 & -7.5 & 532 & 19.6 & 19.5 \\
\hline & 8 & 0 & 8.5 & 9.9 & -1.4 & 994 & 36.5 & 36.4 \\
\hline & 7 & 0 & 7.0 & 8.0 & -1.0 & 570 & 21.0 & 20.9 \\
\hline & 11 & Trace & 8.7 & 9.9 & -1.2 & 858 & 31.5 & 31.4 \\
\hline & 4 & 0 & 5.9 & 8.5 & -2.7 & 529 & 19.5 & 19.4 \\
\hline & 8 & 0 & 8.6 & 8.8 & -0.2 & 840 & 30.9 & 30.8 \\
\hline & 2 & 0 & 4.6 & 9.5 & -4.9 & 360 & 13.2 & 13.2 \\
\hline & 11 & 0 & 8.6 & 9.9 & -1.3 & 832 & 30.6 & 30.5 \\
\hline
\end{tabular}

t The figures printed in heavy type indicate periods in which a positive nitrogen balance was obtained; the figures in lighter print indicate the periods of nitrogen loss.

$\because$ In these instances, the nitrogen of the feces was estimated as 10 per cent. of the nitrogen intake; the remaining flgures represent actual determinations. 
TABLE 4.-Summary of Table 3. Caloric Requirement Necessary to

Produce Nitrogen Equilibrium in Cases of Diabetes Mellitus, as Compared with the Normal Metabolism of Individuals of the Same Age and Sex

\begin{tabular}{|c|c|c|c|c|c|c|c|}
\hline \multirow[b]{2}{*}{ Case } & \multirow[b]{2}{*}{ Ige } & \multirow[b]{2}{*}{ sex } & \multirow[b]{2}{*}{$\begin{array}{c}\text { General } \\
\text { Oondition }\end{array}$} & \multicolumn{3}{|c|}{$\begin{array}{c}\text { Calories per Hour per Square } \\
\text { Meter of Body Surface }\end{array}$} & \multirow{2}{*}{$\begin{array}{c}\text { Caloric } \\
\text { Requirements } \\
\text { Necessary } \\
\text { to Establish } \\
\text { N Equllibrium } \\
\text { as Compared } \\
\text { with Normal } \\
\text { Metabolism }\end{array}$} \\
\hline & & & & $\begin{array}{l}\text { Highest } \\
\text { at which } \\
\text { N Equi- } \\
\text { librium } \\
\text { Was Not } \\
\text { Ob tained }\end{array}$ & $\begin{array}{c}\text { Lowest } \\
\text { at which } \\
N \text { Equi- } \\
\text { librium } \\
\text { Was } \\
\text { Obtained }\end{array}$ & $\begin{array}{c}\text { Normal } \\
\text { Metabo- } \\
\text { lism** }\end{array}$ & \\
\hline $\begin{array}{l}\text { 1, Period } 1 \\
\text { Period } 2\end{array}$ & 38 & $\mathbf{M}$ & Very poor & $\begin{array}{l}41.6 \\
41.6\end{array}$ & $\begin{array}{l}47.2 \\
47.4\end{array}$ & $\begin{array}{l}43.7 \\
43.7\end{array}$ & $\begin{array}{l}8 \text { per cent. higher } \\
8 \text { per cent. higher }\end{array}$ \\
\hline 2 & 35 & $\mathbf{F}$ & Fair & 31.6 & 39.7 & 40.6 & Unchanged \\
\hline 3 & 43 & $\mathbf{M}$ & Poor & 36.3 & 43.7 & 43.7 & Unchanged \\
\hline 4 & 56 & $\mathbf{F}$ & Normal & 18.2 & 27.0 & 36.0 & 25 per cent. lower \\
\hline 5 & 26 & $\mathbf{M}$ & Fair & $\cdots$ & 35.8 & 43.7 & 18 per cent. lower \\
\hline 6 & 35 & $\mathbf{M}$ & Normal & 33.8 & 28.2 & 43.7 & 28 per cent. lower \\
\hline 7 & 41 & $\mathbf{M}$ & Normal & 45.6 & 49.1 & 43.7 & 12 per cent. higher \\
\hline $\begin{array}{l}\text { 8, Period I } \\
\text { Period } 2\end{array}$ & 13 & $\mathbf{M}$ & Normal & $\begin{array}{l}49.7 \\
37.7\end{array}$ & $\begin{array}{l}39.5 \\
51.7\end{array}$ & $\begin{array}{l}54.9 \\
54.9\end{array}$ & $\begin{array}{l}28 \text { per cent. lower } \\
6 \text { per cent. lower }\end{array}$ \\
\hline 9 & 12 & $\mathbf{F}$ & Poor & 36.4 & & & \\
\hline
\end{tabular}

* Basal metabolism according to F. O. Gephart and E. F. Du Bols (Trge ARchives InT. MED., 1916, 17, 902) plus 10 per cent. to allow for the specific dynamic action of the diet.

actually utilized amounted to only 13.9 calories per $\mathrm{kg}$. per day, or 12.9 calories per square meter per hour. This remarkable effect of a low, pure protein-fat diet in conserving the body's nitrogen may be the reason for the fact that this emaciated child was able to "walk around and go riding" three months later, although she was still excreting large amounts of sugar. The present case is one of the rare instances in which a maximal $D: N$ ratio did not prove to be a sign of immediate danger or impending death. The fluctuations manifested in the $\mathrm{D}: \mathrm{N}$ ratio from day to day are similar to those noted in other cases, and may be explained by irregular periods of glucose excretion and retention and not necessarily through inefficiency in the management of the case..$^{14}$

From the clinical point of view it is extremely important to know whether or not it is possible to restore the lost body tissue; in other words, cause an assimilation of nitrogen, on these diets. The generally accepted fact is that it is difficult to cause a prolonged deposition of protein on a protein-fat diet. ${ }^{15}$ Strictly speaking, the "carbohydratefree" diets used in diabetes, as in the present report, contain from 10

14. Mosenthal, H. O., and Lewis, D. S.: Bull. Johns Hopkins Hosp., 1917, 28, 187.

15. Lusk, G.: Science of Nutrition, Ed. 3, 1917, p. 255. 


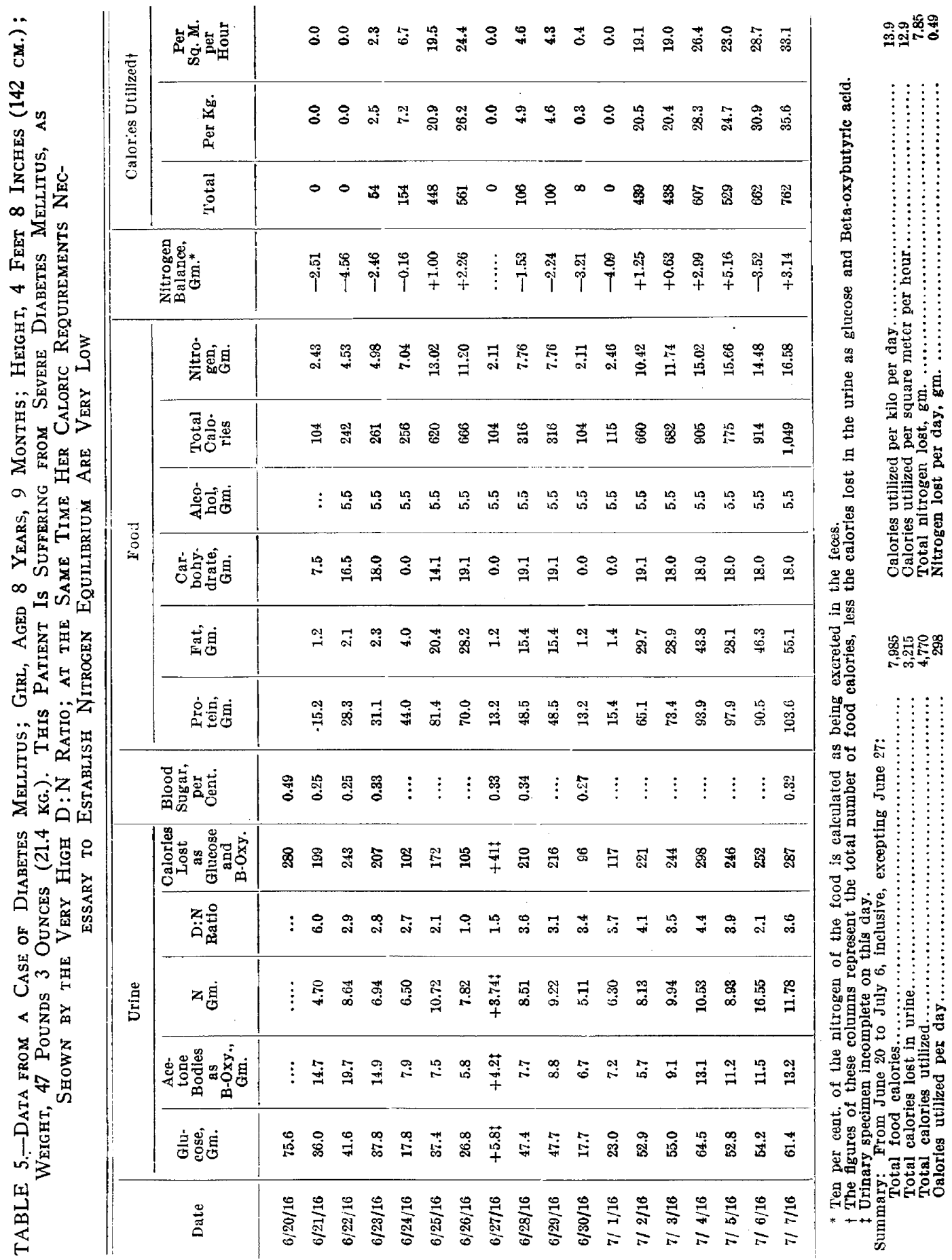


to $15 \mathrm{gm}$. of starch derived from the vegetables. It is rather problematical what effect such a small amount of carbohydrate may have. In some instances, there is no tendency for the body to assimilate nitrogen to any marked degree. This is exemplified in Case 1, Table 3. This patient showed no appreciable rise in his slight positive nitrogen balance when the diet was increased after nitrogen equilibrium had once been obtained, either in the first or second periods of study. On the other hand, some diabetics exhibit the ability to assimilate nitrogen while on "carbohydrate-free" diets. This may be noted in Table 3; Case 2 retained $28 \mathrm{gm}$. of nitrogen in 5 days; Case $4,35 \mathrm{gm}$. in 11 days; Case $5,29 \mathrm{gm}$. in 10 days ; Case $6,34 \mathrm{gm}$. in 16 days, and one diabetic patient of this series whose protocol is not charted, retained $49 \mathrm{gm}$. of nitrogen in 17 days. It is perfectly apparent from these data that the diabetic may often build up body protein while on a carbohydrate-free diet.

A study of Tables 3 and 4 reveals some apparent contradictions: In Cases 6 and 8, the highest caloric value of the food at which nitrogen equilibrium was not obtained is greater than the lowest value at which equilibrium was obtained. These inconsistent results are no more opposed to one another than the very varying heights of metabolism required to produce nitrogen equilibrium in the different cases (Table 4). What the specific reason for the caloric requirement is in each case is impossible to determine; it may be stated definitely, however, from the data of Case 1 (Tables 3 and 4), that these factors may have a tendency to remain constant, although in some individuals they may vary as in Cases 6 and 8 .

In Case 6, Table 3, it is apparent that in the first two periods the nitrogen output is higher, with a lower nitrogen intake than it is in some of the subsequent periods. The same fact may be noted in Case 2 , Tabie 3. In both of these patients there was a considerable glycosuria, while this slight excess of arinary nitrogen manifested itself. It may have been that the caloric loss of the urinary sugar resulted in a greater destruction of protein, or it may be that these are mild examples of the very marked protein breakdown and excessive amounts of urinary nitrogen at times found in diabetes, as in the case of Geyelin and Du Bois. ${ }^{16}$ In either event it is certain that nitrogen equilibrium was established at a considerably lower caloric food level in Case 6 after the glycosuria had subsided. It must be distinctly recognized, however, that the glycosuria in itself, although very marked, need not result in an increased caloric demand to establish nitrogen equilibrium. This is well shown in the case detailed in Table 5.

The discrepancy in Case 8 is well explained in Table 6 , which gives

16. Geyelin, H. R., and Du Bois, E. F.: Jour. Am. Med. Assn., 1916, 66, 1532. 


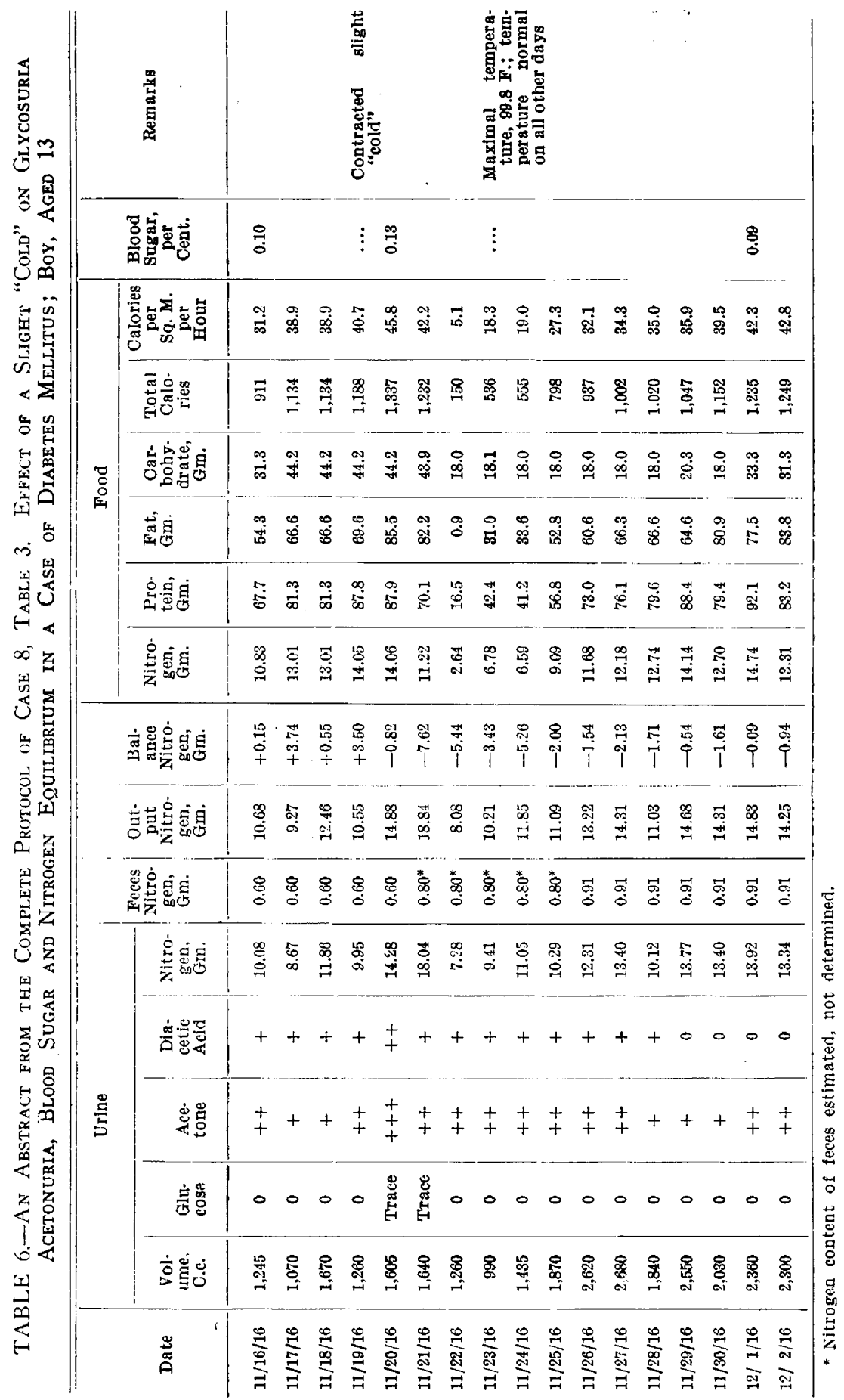


a portion of the protocol in detail. In the first days a nitrogen balance was readily obtained on a diet of about 1,000 calories. On November 19 a definite series of changes appeared. Each one of these variations in itself might not have been worthy of attention, but taking them together they showed that many of the metabolic processes were synchronously affected. The acetone and diacetic acids increased in the urine, as shown by the qualitative tests, a trace of glucose was found in the urine, the nitrogen excretion rose considerably, the nitrogen balance became negative, and the blood sugar increased, although the diet was scarcely changed for three days. All of these phenomena were evidently brought about by a "cold in the head" of so slight a nature that the patient himself scarcely complained of it, and the body temperature only rose to $99.8 \mathrm{~F}$. on one day. All these symptoms promptly rectified themselves with the disappearance of this infection of minimal intensity, except one: the power to establish nitrogen equilibrium at the former low diet level was lost and remained so when the patient was tested out again six weeks later. It is well known that nervous shocks and the severer infections play havoc with the health of diabetics. That a very slight disturbance should have such far-reaching effects is worthy of consideration in the management of these cases.

A study of Tables 3,4 and 5 shows that the general condition of the diabetic, that is, whether his state of nourishment be normal, fair, poor or emaciated, tends to have no direct bearing on the number of calories per square meter per hour required to establish nitrogen equilibrium.

Case 9 (Tables 3 and 4 ) is an instance of a patient in whom nitrogen equilibrium could not be established without the appearance of glucose in the urine. The treatment in this case was to continue the inadequate diet and maintain the urine in a sugar-free condition. The result has been a slow but evidently perceptible loss of weight and strength. Case 4 (Tables 3 and 4), a woman in good circumstances, has continued on the given diet for one year, attending to her social and household duties, and has gained strength and a little weight, although her diet is a low one. In Case 5 (Tables 3 and 4), the patient lias taken the low diet indicated for an interval of 6 months; during this period he has solicited contracts for an engineering company, being on his feet nearly all the time, and feels perfectly strong and well. In Case 7 (Tables 3 and 4) the patient reports that he has taken the 2,000calory carbohydrate-free diet for a period of eight months while he has been working as a farmer, and that his health and strength are good, though he has gained no weight. These few examples may serve to indicate (they are too few to prove the claim) that a diabetic need take only sufficient calories to result in a nitrogen equilibrium in order to bring about a maintenance of health and strength. 
CONCLUSIONS

Diabetic patients may be established in nitrogen equilibrium by a carbohydrate-free diet having a caloric value equal to the standard total caloric requirement. In many instances this may be accomplished at a considerably lower level of feeding. The factors which determine the dietary level at which a diabetic attains a nitrogen balance are apparently very numerous, and not fully determined; glycosuria at times, and infections, even of very slight degree, may necessitate a higher diet to bring about the desired result.

A marked assimilation of nitrogen may occur in diabetics while on a carbohydrate-free diet.

The lowest diet which will conserve the physical and mental efficiency of the diabetic is that which maintains the nitrogen equilibrium of the patient. A rough estimate for clinical purposes of what constitutes a maintenance ration for the diabetic on a carbohydrate-free diet, is from 1,500 to 2,000 calories. In adjusting the value of the diet it should be borne in mind that women and small persons generally require less food than men and larger persons. 